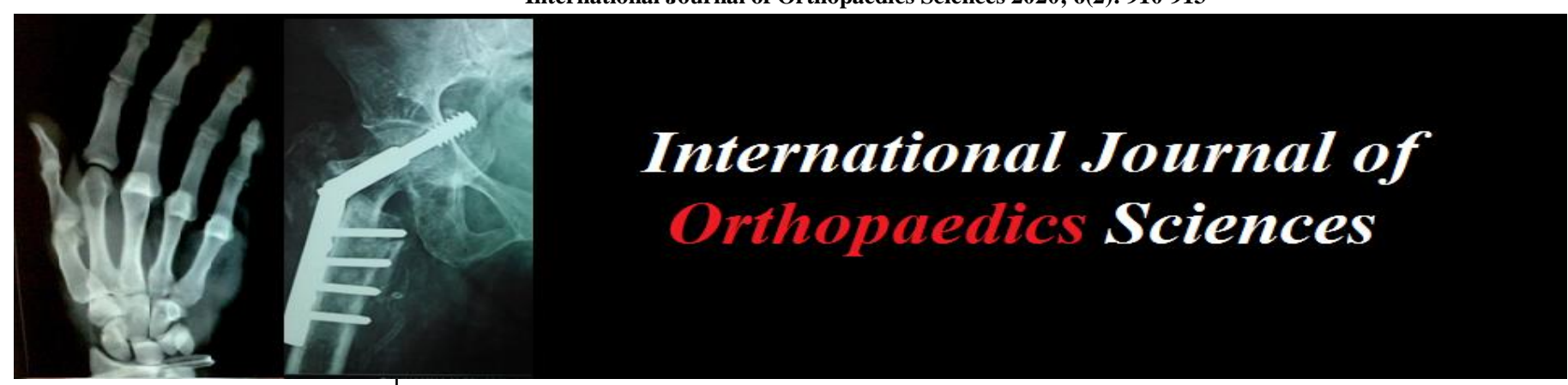

E-ISSN: 2395-1958

P-ISSN: 2706-6630

IJOS 2020; 6(2): 910-913

(C) $2020 \mathrm{IJOS}$

www.orthopaper.com

Received: 22-01-2020

Accepted: 24-02-2020

Dr. Krishanth Krishnathas

Post Graduate,

Department of orthopaedics,

RRMCH Bangalore, Karnataka,

India

Dr. Ullas Mahesh

Assistant Professor,

Department of orthopaedics,

SSIMS, T Begur, Bangalore,

Karnataka, India
Corresponding Author:

Dr. Ullas Mahesh

Assistant Professor,

Department of orthopaedics,

SSIMS, T Begur, Bangalore,

Karnataka, India

\section{Coronal plane "Hoffa" fractures of the distal femoral condyle treatment and outcome}

\author{
Dr. Krishanth Krishnathas and Dr. Ullas Mahesh
}

DOI: https://doi.org/10.22271/ortho.2020.v6.i2o.2159

\section{Abstract}

Introduction: Coronal plane "Hoffa" fractures of the distal femoral condyles are a rare entity. Lateral fractures are three times more common than medial fracture. They are commonly associated with supracondylar fractures of the distal femur however as an isolated injury they are rare.

Results: Union was achieved in all 20 patients. The articular surface was reduced anatomically in all but one patient. There was no loss of reduction or fixation. Functional outcome measures showed a continuous significant improvement in function over the 1-year follow up period. Study period was between Jan 2018- December 2018. Complications include stiffness and pain in one patient, collateral laxity in two patients and progression of arthritis in one patient.

Conclusion: Here, we summarized the injury mechanism, diagnosis, classification, and treatment options of Hoffa fractures.

Keywords: classification, diagnosis, Hoffa fracture, injury mechanism, treatment

\section{Introduction}

Coronal plane Hoffa fractures of the femoral condyle are rare injuries first reported by Hoffain 1904. Patient Series in published literature with more than 10 patients are very few. The lateral side is more commonly injured than the medial side. The mechanism of injury has been reported to be a direct antero-posterior force to the flexed and abducted knee for lateral condylar fractures and direct impact to the medial side of the knee in flexion for a medial condylar fracture. The objective in treatment of these fractures is to achieve anatomical reduction of the articular surface and stable fixation. Generally according to the location of the injury the incisions have been described. For lateral injuries a direct lateral approach and for medial injuries a medial approach. Starr et al described a extensive swashbuckler approach for addressing these fractures. There is paucity of data recommending which surgical approach and what implants and in which configuration are the most appropriate. We have utilized a midline anterior approach for all Hoffa fractures with multidirectional screw fixation. The parapatellar arthrotomy depends on the side of injury. The purpose of this study was to evaluate the clinical outcome of our surgical technique in the treatment of Hoffa fractures.

\section{Discussion}

The so-called 'Hoffa' fracture refers to an isolated, coronally-oriented fracture of either femoral condyle, with intra-articular extension. This rare injury corresponds to the Orthopaedic Trauma Association Type 33-B3 fracture (frontal, partial articular fracture of the distal femur). These injuries have previously been classified. Type 1 fractures extend from an extraarticular location at the junction of the posterior femoral shaft and the proximal aspect of the femoral condyle superiorly to the posterior aspect of the condylar articular surface inferiorly, such that the popliteus tendon insertion and the lateral head of gastrocnemius origin remain attached to the condylar fragment. The anterior cruciate and lateral ligament insertions may be attached to either the condylar or shaft fragment. Type II originate posterior to the posterior femoral shaft-condylar junction, and are therefore potentially entirely intraarticular. Compared to Type I fractures, the aforementioned ligamentous insertions are less likely to be attached to the condylar fragment. In Type III fractures all of the ligamentous insertions remain attached to the condylar fragment. 
No relationship between the incidence of avascular necrosis and fracture type has been conclusively demonstrated. Hoffa fractures are seen in the setting of high velocity, high energy trauma. Four of five patients with isolated Hoffa fractures in one series were involved in motor vehicle accidents. In another series, five of seven fractures were sustained in motor vehicle accidents, while a sixth involved a pedestrian hit by a car. In a large retrospective review of intraarticular distal femoral fractures performed at a large level 1 trauma center, a Hoffa fracture was an associated injury in 77 of 202 supracondylar-intracondylar distal femoral fractures. Of these 77 fractures, 62 were seen in the setting of motor vehicle trauma. A fall from a height appears to be the next most common scenario. While some authors have postulated direct impact with the knee in a flexed position as the mechanism of injury, others have attributed the fracture to simultaneous vertical shear and twisting forces.

The Hoffa fracture pattern has been described in both the medial and lateral femoral condyle. Bicondylar involvement has also been previously reported. As mentioned already, Hoffa fractures are not infrequently seen in conjunction with other femoral fractures, both distally as well as more proximally, in the shaft. There have also been reports of associated patellar and/or quadriceps tendon injury. In one case, the avulsed patellar tendon became incarcerated between the fragments of a Hoffa fracture of the lateral femoral condyle, precluding closed reduction. The association of Hoffa fractures with supracondylar-intracondylar distal femoral fractures has already been noted.

The coronal oblique orientation of the Hoffa fracture makes this injury notoriously difficult to detect on standard anteriorposterior (AP) and lateral radiographs, particularly if the fracture is nondisplaced. In the AP projection, the X-ray beam does not run tangent to the fracture margins. The intact, anterior aspect of the fractured condyle further obscures the fracture. Moreover, the foreshortened fractured condyle may be overlooked as mere varus or valgus malalignment. If nondisplaced, incomplete superimposition of the condyles may be the sign of fracture; however, this subtle finding may be misinterpreted as slight obliquity of an intended lateral radiograph. In the large series evaluating Hoffa fractures in the setting of distal femoral intraarticular fractures, initial AP and lateral radiographs were considered diagnostic in only 66 of 95 cases of unicondylar Hoffa fracture. In 10 cases without preoperative computed tomographic (CT) evaluation, the Hoffa component of the injury was only discovered during intraoperative inspection. In the presented case, subtle cortical disruption at the posterior shaft-condylar junction is questionably identified, even in retrospect. Oblique radiographs may provide additional opportunity to more optimally profile the fracture plane. The diagnosis is much more readily apparent with CT or magnetic resonance imaging (MRI). Although the patient in our presented case was successfully managed conservatively with knee bracing and protected weight-bearing, loss of anatomic alignment of non-displaced Hoffa fractures treated with non-operative management exclusively is well-described. Hoffa fractures are typically reduced and fixed with anterior-to-posterior oriented cancellous screws. When there is metaphyseal extension of the fracture, the fixation is supplemented with a lateral buttress plate. Operative repair lateral condylar Hoffa fractures may be accomplished without violating the articular surface by performing an osteotomy of Gerdy's tubercle and reflecting the iliotibial band to provide adequate visualization. Recently, the durability of posterior-to-anterior screw fixation was compared with anterior-to-posterior fixation in cadaveric femora in which osteotomies had first been performed to simulate Hoffa fractures. The authors showed that those condyles fixed with posterior-to-anterior directed screws showed less displacement when subjected to vertical force compared with anterior-to-posterior screw fixation.

\section{Results}

Many articles on Hoffa fractures were reviewed, and the clinical knowledge base was summarized. High-energy trauma is a common cause of a Hoffa fracture, although lowenergy trauma and iatrogenic injury can also lead to these fractures. Commonly used classifications include the Letenneur classification, a computed tomography (CT) classification, the AO classification, and modified AO classification. Radiography can reveal fracture lines. If radiographic findings are negative in questionable cases, CT and magnetic resonance imaging (MRI) should be performed. Nondisplaced fractures can be managed conservatively; however, they involve a high risk of redisplacement. Open reduction and internal fixation are preferred. For young patients with good compliance, simple medial or lateral condylar fractures can be treated via a medial or lateral parapatellar approach. After fracture exposure, headless compression screws can be inserted perpendicularly to the fracture line from posterior to anterior. For bicondylar fractures, a median parapatellar incision can be used. For complex fractures in patients with osteoporosis or a high body mass index, cannulated screws with antigliding plate fixation should be used.

\section{Conclusion}

Hoffa fractures are intra-articular and are best treated by anatomical reduction and rigid fixation followed by early mobilisation. Open reduction increases the chances of achieving anatomical reduction and gives satisfactory functional results when coupled with aggressive rehabilitation.

\section{Summary}

Improving the accuracy and timeliness of Hoffa fracture diagnosis and improving minimally invasive treatment outcomes remain the focus of orthopedic surgeons. Familiarity with the characteristics of Hoffa fracture on various imaging modalities and an understanding of the mechanism and likelihood of combined injuries contribute to the timely and accurate diagnosis of Hoffa fracture and avoiding misdiagnosis. According to the severity of Hoffa fracture and combined injuries, a reasonable treatment plan can be developed. Further improvements in arthroscopicassisted reduction and other minimally invasive surgery technologies will help improve patient prognosis. 
Table 1: Summary of case series of unicondylar Hoffa fractures

\begin{tabular}{|c|c|c|c|c|c|c|}
\hline Author/s & Cases $^{*}$ & $\begin{array}{c}\text { Surgical } \\
\text { approach }^{\dagger}\end{array}$ & Fixation method & $\begin{array}{c}\text { Post-operative } \\
\text { regimen }^{\S}\end{array}$ & Complications $^{\mathbb{I}}$ & Outcome \\
\hline$\underset{[23]}{\text { Lewis } e t ~ a l}$ & $\begin{array}{l}\text { lateral } 3 \text { (incl. } \\
\text { displaced after non- } \\
\text { operative treatment) }\end{array}$ & $\begin{array}{l}\text { MPPA or direct } \\
\text { lateral between } \\
\text { ITB and bice } \\
\text { femoris }\end{array}$ & $\begin{array}{c}2 \text { non-parallel } \\
\text { PTCS (one AP and } \\
\text { one to femoral } \\
\text { shaft). Small } \\
\text { and large fragment } \\
\text { screws }\end{array}$ & $\begin{array}{c}\text { Extension cylinder cast } \\
\text { for } 2 \text { weeks. If fixation } \\
\text { secure early mobilisa } \\
\text { tion or cylinder cast for } 6 \\
\text { weeks }\end{array}$ & None & $\begin{array}{l}\text { 1Surgical fixation: } \\
\text { good, \&1 fair. Non- } \\
\text { operative: } 1 \text { fair, } 1 \\
\text { poor. Mean follow- } \\
\text { up } 12 \text { months ( } 12 \text { to } \\
17 \text { ) }\end{array}$ \\
\hline$\underset{[8]}{\text { Holmes }}$ et al & $\begin{array}{l}\text { medial } 1 \& \text { lateral } 2 \\
\text { (incl. } 1 \text { nonunion after } \\
\text { non-operative } \\
\text { treatment with a pre- } \\
\text { operative FF } 20^{\circ} \text { ) }\end{array}$ & MPPA or LPPA & $\begin{array}{l}\text { AP. Multiple } \\
\text { parallel 3.5-mm } \\
\text { screws }\end{array}$ & $\begin{array}{c}\text { Unrestricted ROM } \\
\text { exercises. Limited } \\
\text { weight-bearing initially, } \\
\text { full weight-bearing at } 10 \\
\text { weeks } \\
\end{array}$ & None & $\begin{array}{l}\text { Mean Knee Society } \\
\text { score } 173(160-180) \\
\text { for } 3 \text { patients. Mean } \\
\text { follow- up } 12 \text { months }\end{array}$ \\
\hline $\begin{array}{l}\text { Ostermann } \\
\quad \text { et al }\end{array}$ & $\begin{array}{l}3 \text { unicondylar distal } \\
\text { femur fractures) }\end{array}$ & - & $\begin{array}{l}\text { AP. Right angles to } \\
\text { femoral shaft. } \\
\text { Positioned as far } \\
\text { laterally as possible } \\
\text { to avoid articular } \\
\text { surface, or } \\
\text { countersunk }\end{array}$ & $\begin{array}{l}\text { CPM day 1. ROM } \\
\text { exercises day } 4 . \\
\text { 'Eggshell' weight-bear- } \\
\text { ing at } 1 \text { week, full } \\
\text { weight-bearing } 6 \text { to } 8 \\
\text { weeks }\end{array}$ & - & - \\
\hline $\begin{array}{l}\text { Kumar and } \\
\text { Malhotra }\end{array}$ & 2 lateral & Direct lateral & $\begin{array}{l}\text { AP. } 26.5-\mathrm{mm} \\
\text { PTCS }\end{array}$ & $\begin{array}{l}90^{\circ} \text { flexion of knee in } \\
\text { plaster at } 24 \text { hours. } \\
\text { ROM exercises. } \\
\text { Full weight-bearing } \\
\text { at } 16 \text { weeks }\end{array}$ & None & $\begin{array}{l}\text { excellent (Neer func- } \\
\text { tional rating score). } \\
\text { Mean follow-up } 42 \\
\text { months (12 to } 96)\end{array}$ \\
\hline $\begin{array}{l}\text { Manfredini } \\
\text { et }_{\text {al }}^{[1]}\end{array}$ & $\begin{array}{l}3 \text { unicondylar distal } \\
\text { femur fractures }\end{array}$ & $\begin{array}{l}\text { Small medial or } \\
\text { lateral decision }\end{array}$ & - & $\begin{array}{c}\text { Posterior articulated } \\
\text { splint for mean } 25 \text { days. } \\
\text { CPM after } 96 \text { hours } \\
\text { post-op. Weight-bearing } \\
\text { at } 70 \text { days }\end{array}$ & - & - \\
\hline Chang et $a l$ & $\begin{array}{l}2 \text { medial; both patients } \\
\text { had poliomyelitis }\end{array}$ & $\begin{array}{c}\text { Percutaneous (1) } \\
\text { and open approach } \\
\text { (1) }\end{array}$ & $\begin{array}{l}\text { AP. } 2 \text { Acutrak } \\
\text { screws }\end{array}$ & $\begin{array}{c}\text { Non-weight-bearing to } 6 \\
\text { weeks. Partial } \\
\text { weight-bearing } 6 \text { to } \\
12 \text { weeks }\end{array}$ & $\begin{array}{c}\text { Open case: fracture } \\
\text { displacement at } 2 \text { wks. } \\
\text { Revision incl. MPPA, } 4.5- \\
\text { mm DCP (buttress plate) with } \\
34.5 \text {-mm cortical screws } \\
\text { proximal to fracture site. } 2 \\
\text { Acutrak screws AP and } 4.5 \text { - } \\
\text { mm cor- tical screw with } \\
\text { washer from medial condyle } \\
\text { positioned proximally and } \\
\text { laterally }\end{array}$ & $\begin{array}{l}\text { ROM from } 0^{\circ} \text { to } 100^{\circ} \\
\text { for percutaneous case } \\
\text { (Follow-up } 9 \text { months) } \\
\text { and } 0^{\circ} \text { to } 110^{\circ} \text { for } \\
\text { revised open case } \\
\text { (follow-up } 5 \text { months) }\end{array}$ \\
\hline $\begin{array}{c}\text { Miyamoto et } \\
a l^{[13]}\end{array}$ & $\begin{array}{l}1 \text { medial, with } \\
\text { ipsilateral femoral } \\
\text { shaft fracture }\end{array}$ & - & $\begin{array}{l}\text { AP. } 23.5-\mathrm{mm} \\
\text { cortical screws }\end{array}$ & $\begin{array}{c}\text { Active and passive } \\
\text { ROM exercises from day } \\
1 \text { post-op. Non-weight- } \\
\text { bearing to } 6 \text { weeks }\end{array}$ & None & $\begin{array}{l}\text { No pain and full ROM } \\
\text { at 3-month follow-up }\end{array}$ \\
\hline$\underset{[35]}{\operatorname{Borse} e t}$ al & 1 lateral & $\begin{array}{l}\text { Mini anterolateral } \\
\text { parap atellar } \\
\text { arthrotomy }\end{array}$ & $\begin{array}{c}\text { AP. } 2 \text { Acutrak } \\
\text { screws }(30-\mathrm{mm})\end{array}$ & $\begin{array}{l}\text { Knee extension splint } \\
\text { for } 2 \text { weeks. ROM } \\
\text { brace increase flexion } \\
\text { by } 30^{\circ} \text { every } 2 \text { weeks } \\
\text { Non- weight-bearing to } \\
13 \text { weeks }\end{array}$ & None & $\begin{array}{l}\text { Active ROM } 0^{\circ} \text { to } 90^{\circ} \text {. } \\
\text { 12-month follow-up }\end{array}$ \\
\hline $\begin{array}{l}\text { Ocguder } e t \\
a l^{[9]}\end{array}$ & $\begin{array}{l}1 \text { medial, with } \\
\text { ipsilateral tibial spine } \\
\text { avulsion and PCL } \\
\text { rupture }\end{array}$ & MPPA & $\begin{array}{l}\text { AP. } 2 \text { Acutrak } \\
\text { screws }\end{array}$ & $\begin{array}{c}\text { ROM exercises with } \\
\text { physiotherapist from } \\
3 \text { weeks. Partial weight- } \\
\text { bearing at } 6 \text { weeks. Full } \\
\text { weight-bearing at } 12 \\
\text { weeks }\end{array}$ & $\begin{array}{c}\text { At } 5 \text { months post- } \\
\text { op ROM } 0^{\circ} \text { to } \\
35^{\circ} \text {. Modified Judet's } \\
\text { Quadricepsplasty performed }\end{array}$ & $\begin{array}{l}\text { ROM } 130^{\circ} \text { flexion. } 5- \\
\text { month follow-up }\end{array}$ \\
\hline$\underset{[45]}{\text { Vaishya } \text { et } a l}$ & $\begin{array}{l}1 \text { lateral, with } \\
\text { ipsilateral patellar } \\
\text { dislocation }\end{array}$ & LPPA & $\begin{array}{l}\text { AP. } 26.5-\mathrm{mm} \\
\text { PTCS }\end{array}$ & $\begin{array}{c}\text { Cylinder cast for } \\
2 \text { weeks. Knee brace } \\
\text { and ROM exercises for } 2 \\
\text { weeks. Full weight- } \\
\text { bearing at } 6 \text { weeks }\end{array}$ & None & $\begin{array}{l}\text { Full ROM at 2- } \\
\text { year follow-up }\end{array}$ \\
\hline
\end{tabular}

\section{References}

1. Calmet J, Mellado JM, Forcada G, Gine J. Open bicondylar Hoffa fracture associated with extensor mechanism injury. J Orthop Trauma. 2004; 18:323-325.

2. Hak DJ, Nguyen J, Curtiss S, Hazelwood S. Coronal fractures ofthe distal femoral condyle: a biomechanical evaluation of fourinternal fixation constructs. Injury. 2005; 36:1103-1106
3. Jarit GJ, Kummer FJ, Gibber MJ, Egol KA.A mechanicalevaluation of two fixation methods using cancellous screws forcoronal fractures of the lateral condyle of the distal femur (OTA type33B). J Orthop trauma. 2006; 20:273-276.

4. Ocguder A, Bozkurt M, Kalkan T, Ugurlu M, Kilicarslan K. Hoffafracture, ementia fracture and posterior cruciate ligament damage: an unusual knee injury. Injury extra 
2008; 39:88-91.

5. Kumar R, Malhotra R. The Hoffa fracture: three case reports. JOrthop Surg (Hong Kong) 2001; 9:47-51

6. Butt MS, Krikler SJ, Ali MS. Displaced fractures of the distal femur in elderly patients: operative versus nonoperative treatment. J Bone Joint Surg [Br]. 1996; 78B:110-114.

7. Martelli S, Pinskerova V. The shapes of the tibial and femoral articular surfaces in relation to tibiofemoral movement. J Bone Joint Surg [Br] 2002; 84-B:607-613.

8. No authors listed. Fracture and dislocation compendium: Orthopaedic Trauma Asso- ciation Committee for Coding and Classification. J Orthop Trauma 1996; 10(1):1-154.

9. Baker BJ, Escobedo EM, Nork SE, Henley MB. Hoffa fracture: a common asso- ciation with high-energy supracondylar fractures of the distal femur. AJR Am J Roent-genol. 2002; 178:994.

10. Kumar R, Malhotra R. The Hoffa fracture: three case reports. J Orthop Surg (Hong Kong). 2001; 9:47-51. 